\title{
Characteristics associated with complete surgical resection of primary malignant mediastinal tumors*,**
}

\author{
Características associadas à ressecção cirúrgica completa \\ de tumores malignos primários do mediastino
}

\author{
Jefferson Luiz Gross, Ulisses Augusto Correia Rosalino, Riad Naim Younes,
} Fábio José Haddad, Rodrigo Afonso da Silva, Antonio Bomfim Marçal Avertano Rocha

\begin{abstract}
Objective: To identify preoperative characteristics associated with complete surgical resection of primary malignant mediastinal tumors. Methods: Between 1996 and 2006, 42 patients with primary malignant mediastinal tumors were submitted to surgery with curative intent at a single facility. Patient charts were reviewed in order to collect data related to demographics, clinical manifestation, characteristics of mediastinal tumors and imaging aspects of invasiveness. Results: The surgical resection was considered complete in $69.1 \%$ of the patients. Cases of incomplete resection were attributed to invasion of the following structures: large blood vessels (4 cases); the superior vena cava ( 3 cases); the heart ( 2 cases); the lung and chest wall (3cases); and the trachea ( 1 case). Overall survival was significantly better among the patients submitted to complete surgical resection than among those submitted to incomplete resection. The frequency of incomplete resection was significantly higher in cases in which the tumor had invaded organs other than the lung (as identified through imaging studies) than in those in which it was restricted to the lung $(47.6 \%$ vs. $14.3 \% ; p=0.04)$. None of the other preoperative characteristics analyzed were found to be associated with complete resection. Conclusions: Preoperative radiological evidence of invasion of organs other than the lung is associated with the incomplete surgical resection of primary malignant mediastinal tumors.
\end{abstract}

Keywords: Thoracic surgery; Survival rate; Mediastinal neoplasms; Diagnostic imaging.

\section{Resumo}

Objetivo: Identificar características pré-operatórias associadas à ressecção cirúrgica completa de tumores malignos primários do mediastino. Métodos: Entre os anos de 1996 e 2006, 42 pacientes com tumores malignos primários do mediastino foram submetidos a tratamento cirúrgico com intenção curativa em uma única instituição. Dados demográficos, manifestações clínicas, características do tumor mediastinal e aspectos de invasão por métodos de imagem foram identificados através da análise de prontuários. Resultados: A ressecção cirúrgica foi considerada completa em $69,1 \%$ dos pacientes. As causas de ressecção incompleta foram atribuídas à invasão das seguintes estruturas: grandes vasos (4 casos); veia cava superior ( 3 casos); coração (2 casos); pulmão e parede torácica ( 3 casos); e traqueia ( 1 caso). Os pacientes que foram submetidos à ressecção cirúrgica completa tiveram sobrevida global significativamente melhor que os pacientes submetidos à ressecção incompleta. A frequência de ressecção incompleta foi significativamente maior nos casos nos quais foram identificadas características radiológicas de invasão de outros órgãos além do pulmão do que nos casos cujas características eram restritas ao pulmão $(47,6 \%$ vs. $14,3 \% ; p=0,04)$. Nenhuma das outras características pré-operatórias analisadas foi associada com a ressecção cirúrgica completa. Conclusões: Evidências radiológicas de invasão de órgãos além do pulmão no pré-operatório estão associadas à ressecção cirúrgica incompleta de tumores primários malignos do mediastino.

Descritores: Cirurgia torácica; Taxa de sobrevida; Neoplasias do mediastino; Diagnóstico por imagem.

\footnotetext{
* Study carried out in the Department of Thoracic Surgery. A. C. Camargo Hospital, São Paulo, Brazil.

Correspondence to: Jefferson Luiz Gross. Departamento de Cirurgia Torácica, Hospital A. C. Camargo, Rua Professor Antonio Prudente, 211, Liberdade, CEP 01509-010, São Paulo, SP, Brasil.

Tel 5511 3277-7720. E-mail: jefluizgross@yahoo.com.br

Financial support: None.

Submitted: 6 February 2009. Accepted, after review: 15 May 2009.

** A versão completa em português deste artigo está disponível em www.jornaldepneumologia.com.br
} 


\section{Introduction}

Mediastinal tumors are rare and include a range of different diseases..$^{(1,2)}$ Malignant mediastinal tumors can be primary or metastatic from other sites. Surgery, ranging from biopsy to radical resection, plays an essential role in the management of most primary malignant mediastinal tumors. In addition, surgery can be part of multimodal therapeutic approaches, including chemotherapy or radiotherapy. Surgical resection is rarely used as the sole treatment for primary malignant mediastinal tumors. ${ }^{(3,4)}$

Since primary malignant mediastinal tumors are rare and heterogeneous, there have been few studies reporting the role of surgical resection in the management of such tumors. Most studies evaluating the management of thoracic tumors have evaluated various benign and malignant diseases arising in different mediastinal compartments. Other studies evaluating surgical resection as the primary treatment for tumors arising in the mediastinum were published more than 20 years ago. ${ }^{(5-7)}$ Since then, surgical and anesthetic techniques have improved considerably. Patient characteristics, indications for resection and overall outcomes of surgery have changed significantly. Thymomas and nonseminomatous germ-cell tumors are the primary malignant mediastinal tumors for which surgical treatment is most often applied. ${ }^{(8)}$

Complete resection has been shown to be a significant determinant of prognosis among patients submitted to surgery for the treatment of invasive primary mediastinal tumors. ${ }^{(9)}$ Age, together with the characteristics of preoperative imaging studies determining the location and consistency of mediastinal tumors, can suggest the diagnosis and the likelihood of malignancy. ${ }^{(1,10-12)}$ However, the factors predicting the resectability of such tumors have not been reported. The aim of the present study was to identify preoperative characteristics associated with the ability to achieve complete surgical resection in a group of patients with primary malignant mediastinal tumors.

\section{Methods}

This was a retrospective study of 42 patients with primary malignant mediastinal tumors submitted to surgery with curative intent. All patients underwent surgical treatment at our facility between March of 1986 and August of 2006. Inclusion criteria were histological diagnosis of malignant primary mediastinal tumor and surgical treatment with the objective of radical resection. Patients with mediastinal lymphomas were excluded, as were those with tumors arising from the trachea, esophagus or lung and those with mediastinal goiters.

Data related to demographic characteristics, clinical manifestation, mediastinal tumor location, invasion of adjacent organs, preoperative (neoadjuvant) treatment, type of thoracic incision and resectability were collected through a review of individual patient charts. In order to classify tumor location, the mediastinum was divided into three compartments (anterior, middle and posterior) based on a review of radiology reports. All patients were submitted to preoperative imaging studies-either chest CT or the combination of chest $\mathrm{CT}$ and magnetic resonance imaging (MRI), at the discretion of the surgeon-and data regarding the infiltration of adjacent organs were classified according to the radiology reports. Complete surgical resection was defined as complete removal of all macroscopic tumor; and incomplete surgical resection was defined as no resection or partial resection.

Median age was 39.5 years (range, 1.0-77.4 years), and 30 (71.5\%) of the 42 patients were male. Five patients were asymptomatic. The most common initial clinical manifestation was chest pain, which was reported by 18 patients $(42.8 \%)$. The median duration of symptoms was 4 months (range, 1-36 months). The majority $(73.8 \%)$ of the tumors were located in the anterior mediastinal compartment, whereas 19.1\% were located in the posterior compartment, and $7.1 \%$ were located in the middle compartment. Thymic malignant neoplasms and germ-cell tumors were the two most common histologic

Table 1 - Histologic type of malignant primary mediastinal tumors.

\begin{tabular}{lrr}
\hline \multicolumn{1}{c}{ Histological type } & $\mathrm{n}$ & \multicolumn{1}{c}{$\%$} \\
\hline Thymic neoplasm & 15 & 35.7 \\
Thymoma & 11 & 26.1 \\
Carcinoma & 2 & 4.8 \\
Neuroendocrine carcinoma & 2 & 4.8 \\
Germ-cell tumor & 13 & 30.9 \\
Soft tissue sarcoma & 6 & 14.3 \\
Neurogenic tumor & 6 & 14.3 \\
Undifferentiated malignant neoplasm & 2 & 4.8 \\
\hline
\end{tabular}


types, as shown in Table 1. According to the radiology reports, the tumor was restricted to the mediastinum, without invasion of adjacent structures, in 14 patients (33.3\%). Among the remaining 28 patients $(66.6 \%)$ in whom there was radiologic evidence of a tumor infiltrating adjacent organs, there was invasion of the lung parenchyma in 18, invasion of large blood vessels in 5 , invasion of the pericardium in 6 and invasion of the chest wall in 7. All 28 of those patients were submitted to surgery as the primary treatment. Preoperative chemotherapy was administered to $13(31.0 \%)$ of the 42 patients. One patient (2.4\%) was treated with chemotherapy and radiation therapy prior to surgical resection. The type of thoracic surgical access was selected by the attending surgeon on a case-by-case basis. The most common surgical approach was median sternotomy, employed in 19 patients (45.3\%); followed by left lateral thoracotomy, employed in 14 (25.0\%); and right lateral thoracotomy, employed in 9 (21.4\%). Resection of adjacent structures was performed in 24 patients (57.2\%). The lung parenchyma was the structure most frequently excised: wedge/ segmentectomy was performed in 12 patients (28.6\%); lobectomy was performed in $2(4.8 \%)$; and pneumonectomy was performed in 1 (2.4\%). The following were also resected: the adjacent pericardium in 5 patients $(11.9 \%)$; the parietal pleura in $5(11.9 \%)$; the chest wall in $4(9.6 \%)$; the phrenic nerve in $2(4.8 \%)$; and the superior vena cava (partial resection) in $1(2.4 \%)$.

\section{Statistical analysis}

Overall survival, from the date of surgery to the date of death or the last clinical evaluation, was estimated by the Kaplan-Meier method. The influence that the type of resection (complete or incomplete) had on overall survival was calculated, and comparisons were performed using the log-rank test. The chi-square and Fisher's exact tests were used, as appropriate, to assess associations between the type of surgical resection and the following variables: demographic data; histologic type; tumor location; invasion of adjacent structures; surgical approach; preoperative treatment; and status at admission. Values of $p<0.05$ were considered statistically significant. Statistical analyses were performed using the program Statistical Package for the Social Sciences, version 11.5 (SPSS Inc, Chicago, IL, USA).
Table 2 - Association between characteristics of the patients and resectability of mediastinal tumors.

\begin{tabular}{lccc}
\hline Characteristic & $\begin{array}{c}\text { Complete } \\
\text { resection, } \\
\mathrm{n}(\%)\end{array}$ & $\begin{array}{c}\text { Incomplete } \\
\text { resection, } \\
\mathrm{n}(\%)\end{array}$ & $\mathrm{p}^{*}$ \\
\hline $\begin{array}{l}\text { Gender } \\
\quad \text { Male }\end{array}$ & $20(66.7)$ & $10(33.3)$ & 0.59 \\
$\quad$ Female & $9(75.0)$ & $3(25.0)$ & \\
Age & & & \\
$\quad \leq 40$ years & $14(63.6)$ & $8(36.4)$ & 0.43 \\
$>40$ years & $15(75.0)$ & $5(25.0)$ & \\
\hline
\end{tabular}

*chi-square test or Fisher's exact test.

\section{Results}

Among the 42 patients evaluated, surgical resection was considered complete in $29(69.1 \%)$ and incomplete in the remaining 13 (30.9\%). Incomplete resection was attributed to tumor invasion of the following structures: large blood vessels (in 4 cases); the superior vena cava (in 3 cases); the heart (in 2 cases); the lung and chest wall (in 3 cases); and the trachea (in 1 case). Among the 13 patients in whom the resection was incomplete, radiotherapy was administered in 6 , chemotherapy was administered in 3, and the chemotherapy-radiotherapy combination was administered in 3. One patient with malignant mesenchymoma received no postoperative treatment and died two months after the surgical procedure due to the progression of malignant disease.

The median follow-up time was 21.5 months (range, 0.2-183 months). Overall five-year survival was $71.3 \%$. Patients submitted to complete surgical resection had significantly better overall survival than did those submitted to incomplete resection $(84.4 \%$ vs. $42.9 \%$,

Table 3 - Chest pain and symptom duration (all symptoms): association with resectability of mediastinal tumors.

\begin{tabular}{|c|c|c|c|}
\hline Variable & $\begin{array}{l}\text { Complete } \\
\text { resection, } \\
\mathrm{n}(\%)\end{array}$ & $\begin{array}{l}\text { Incomplete } \\
\text { resection, } \\
\text { n }(\%)\end{array}$ & $p^{*}$ \\
\hline \multicolumn{4}{|l|}{ Chest pain } \\
\hline Yes & $9(52.9)$ & $8(47.1)$ & 0.08 \\
\hline No & $17(81.0)$ & $4(19.0)$ & \\
\hline \multicolumn{4}{|c|}{ Duration of symptoms } \\
\hline$\leq 4$ months & $13(72.2)$ & $5(27.8)$ & 0.26 \\
\hline$>4$ months & $8(53.3)$ & 7 (48.7) & \\
\hline
\end{tabular}

${ }^{*}$ chi-square test or Fisher's exact test. 
Table 4 - Tumor location, type of surgical approach, preoperative treatment and histologic type: association with resectability of mediastinal tumors.

\begin{tabular}{|c|c|c|c|}
\hline Variable & $\begin{array}{c}\text { Complete } \\
\text { resection, } \\
\text { n }(\%)\end{array}$ & $\begin{array}{l}\text { Incomplete } \\
\text { resection, } \\
\text { n }(\%)\end{array}$ & $\mathrm{p}^{*}$ \\
\hline \multicolumn{4}{|l|}{ Tumor location } \\
\hline $\begin{array}{l}\text { Anterior } \\
\text { mediastinum }\end{array}$ & $23(74.2)$ & $8(25.8)$ & 0.23 \\
\hline Other & $6(54.5)$ & $5(45.5)$ & \\
\hline \multicolumn{4}{|c|}{ Type of surgical approach } \\
\hline Sternotomy & 15 (78.9) & $4(21.1)$ & 0.31 \\
\hline $\begin{array}{l}\text { Lateral } \\
\text { thoracotomy }\end{array}$ & $14(60.9)$ & $9(39.1)$ & \\
\hline \multicolumn{4}{|c|}{ Preoperative treatment } \\
\hline Yes & $21(75.0)$ & $7(25.0)$ & 0.24 \\
\hline No & $8(57.1)$ & $6(42.9)$ & \\
\hline \multicolumn{4}{|l|}{ Histological type } \\
\hline Thymic & $11(73.3)$ & $4(26.7)$ & 0.74 \\
\hline Non-thymic & $18(66.7)$ & 9 (33.3) & \\
\hline
\end{tabular}

*chi-square test or Fisher's exact test.

$p=0.04)$. The number of censored cases at 20, 40 and 60 months, respectively, was as follows: complete resection: 16,8 and 4 patients; and incomplete resection: 5, 4 and 3 patients.

Gender and age were not associated with the resectability of mediastinal tumors (Table 2). Patients with chest pain as an initial clinical manifestation tended to be unresectable at surgery. Table 3 shows that resection was incomplete in $47.1 \%$ of such patients. However, this difference did not reach statistical significance $(p=0.08)$.

The anatomical location of the primary malignant tumor (anterior, middle or posterior

Table 5 - Association between preoperative radiological evidence of tumor invasion and resectability of mediastinal tumors.

\begin{tabular}{cccc}
\hline $\begin{array}{c}\text { Radiological } \\
\text { evidence }\end{array}$ & $\begin{array}{c}\text { Complete } \\
\text { resection, } \\
\mathrm{n}(\%)\end{array}$ & $\begin{array}{c}\text { Incomplete } \\
\text { resection, } \\
\mathrm{n}(\%)\end{array}$ & $\mathrm{p}^{*}$ \\
\hline $\begin{array}{c}\text { Invasion of adjacent organs } \\
\text { Yes } \\
\text { No }\end{array}$ & $17(60.7)$ & $11(39.3)$ & 0.16 \\
Invasion of the lung \\
Yes & $2(14(61.1)$ & $7(38.9)$ & 0.51 \\
No & $18(75.0)$ & $6(25.0)$ & \\
Invasion of organs other than the lung & \\
Yes & $11(52.4)$ & $10(47.6)$ & 0.04 \\
No & $18(85.7)$ & $3(14.3)$ & \\
\hline
\end{tabular}

*chi-square test or Fisher's exact test. mediastinal compartment) was not associated with the ability to achieve complete resection; nor was the type of surgical approach (sternotomy or lateral thoracotomy). As can be seen in Table 4, the same was true for preoperative treatment (neoadjuvant treatment or no treatment) and histologic type of the primary mediastinal malignancy (thymic or non-thymic).

In all cases, chest CT or chest CT plus MRI was performed in order to identify invasion of anatomic structures adjacent to the mediastinal tumor.

Resectability was not associated with invasion of mediastinal structures, defined in preoperative imaging evaluation. Refinement of this analysis revealed that tumor invasion of the lung parenchyma was not associated with resectability. However, invasion of organs other than the lung was strongly associated with resectability. Among the 14 patients in whom there was no invasion of these anatomical structures, complete resection was achieved in 12 (85.7\%), compared with $17(60.7 \%)$ of the 28 in whom there was such invasion (Table 5). Involvement of anatomic structures other than the lung was as follows: the heart and large blood vessels (in 8 cases); the chest wall (in 7 cases); the pericardium (in 5 cases); and the esophagus (in 1 case).

\section{Discussion}

There have been few studies dedicated to analyzing patients with primary mediastinal tumors. Most studies evaluating the management of thoracic tumors have included patients with various benign and malignant tumors, treated over long periods. . $^{(1,13-16)}$

The present study evaluated a group of patients with primary malignant mediastinal neoplasms of various histologic types. However, all of the patients were submitted to surgical procedures with curative intent. We selected this specific group of patients in order to identify preoperative factors associated with the ability to achieve complete surgical resection.

Although the present study involved at least six different histologic types of primary mediastinal tumors, it is not as heterogeneous as some other studies, which have included lymphomas and various types of benign tumors. ${ }^{(16-18)}$ Lymphomas have been included even in studies that selected patients submitted to surgical resection of malignant mediastinal tumors, 
despite the fact that surgery plays a limited role in the management of mediastinal lymphomas. Accordingly, we decided to exclude patients with lymphomas. In surgical studies of malignant mediastinal tumors, ${ }^{(9,19-21)}$ thymic neoplasms, mainly thymomas, and primary malignant germ-cell tumors are the histologic types most frequently described, as was also observed in the present study. Another common critique of previous studies of mediastinal tumors is that patients were treated over a long period, during which the therapeutic strategies changed. Because of the low incidence of primary malignant mediastinal tumors, the present study described patients treated during a 20-year period, similar to other published studies..$^{(9,16)}$

Other studies ${ }^{(7)}$ have reported the surgical treatment of mediastinal neoplasms invading adjacent anatomical structures and requiring extensive surgical resection, followed by reconstructive techniques. ${ }^{(9,16)}$ The authors of those studies concluded that complete resection is a significant determinant of long-term survival. Our results confirm that patients submitted to complete surgical resection had better overall survival than did those submitted to incomplete resection. One group of authors reported an overall five-year survival rate of 70\% among patients undergoing complete surgical resection, ${ }^{(9)}$ similar to the $85 \%$ observed in our group of patients. Despite the evident impact of complete surgical resection on overall survival, it was not clear whether certain preoperative characteristics can predict the resectability of primary malignant mediastinal tumors.

Complete surgical resection was obtained in $69.1 \%$ of the patients evaluated in the present study, similar to the $79 \%$ reported in another study, involving 89 patients. ${ }^{(9)}$ These results suggest that incomplete surgical resection occurs in 20-30\% of cases, even when patients undergo appropriate preoperative evaluation. The aim of the present study was to identify preoperative characteristics associated with the ability to achieve complete surgical resection. In a review of the literature, we identified no studies dedicated to this issue. One potential limitation of the present study is that, as a retrospective analysis, the completeness of surgical resection was defined based on data collected from patient charts.
One of the most common clinical manifestations, chest pain, was observed in $66.7 \%$ of the patients submitted to incomplete resection, compared with only $34.6 \%$ of those submitted to complete resection, although this difference did not reach statistical significance $(p=0.08)$. This finding suggests that chest pain is associated with locally advanced tumors and with lower probability of complete surgical resection. Some authors have described chest pain as a predictor of survival among patients with chest wall tumors. ${ }^{(22)}$ However, there is no data regarding this characteristic in patients with primary malignant mediastinal neoplasms. Chest pain might be related to chest wall invasion by mediastinal tumors or even to invasion of other adjacent anatomical structures. Invasion of the chest wall (sternum or ribs) should not present technical obstacles to complete surgical resection, since sternum and ribs can be resected with adequate margins. Therefore, we believe that any association between chest pain and resectability is not related to the extent of local invasion, although no definitive conclusion can be made based on the data currently available.

Although imaging of mediastinal tumors is typically performed using chest CT, MRl can be used in order to define great vessel invasion or to identify invasion of the vertebral body. Both radiological methods are employed in order to determine tumor invasion of adjacent anatomical structures. ${ }^{(23)}$ One group of authors assessed the value of CT and MRI in evaluating mediastinal tumors and concluded that both provide essentially the same information. ${ }^{(24)}$ All of the patients evaluated in the present study were submitted to chest CT. However, MRI was also performed in certain cases, which were few in number, since MRI has only become available at our institution in the last ten years and was indicated only in specific situations.

To our knowledge, this is the first study correlating radiological findings with the probability of achieving complete surgical resection of mediastinal tumors. We found that radiological invasion of lung parenchyma did not correlate with tumor resectability, probably because resection of the lung parenchyma (wedge resection or even lobectomy) can be easily accomplished en bloc with the mediastinal mass. However, invasion of structures other than the lung are directly correlated with inability to achieve complete 
resection of mediastinal tumors. Invasion of large blood vessels was the most common radiological characteristic leading to incomplete surgical resection of mediastinal tumors.

Although the location of mediastinal mass is critical to differential diagnosis of primary malignant mediastinal tumors, ${ }^{(1)}$ our results show that this characteristic did not affect the ability to achieve complete surgical resection. Similarly, the type of surgical approach (sternotomy or thoracotomy) was not found to be associated with the completeness of resection. The type of surgical access should be considered in order to achieve adequate viewing and complete resection with tumor-free margins.

We concluded that patients with primary malignant mediastinal tumors who are surgical candidates should be evaluated preoperatively in order to achieve complete surgical resection, which is associated with better survival. Radiological evidence of invasion of organs other than the lung is associated with incomplete surgical resection.

\section{References}

1. Duwe BV, Sterman DH, Musani Al. Tumors of the mediastinum. Chest. 2005;128(4):2893-909.

2. Cohen AJ, Thompson L, Edwards FH, Bellamy RF. Primary cysts and tumors of the mediastinum. Ann Thorac Surg. 1991;51(3):378-84; discussion 385-6.

3. Temes R, Chavez T, Mapel D, Ketai L, Crowell R, Key C, et al. Primary mediastinal malignancies: findings in 219 patients. West J Med. 1999;170(3):161-6.

4. Wongsangiem M, Tangthangtham A. Primary tumors of the mediastinum: 190 cases analysis (1975-1995). J Med Assoc Thai. 1996;79(11):689-97.

5. Adkins RB Jr, Maples MD, Hainsworth JD. Primary malignant mediastinal tumors. Ann Thorac Surg. 1984;38(6):648-59.

6. Davis RD Jr, Oldham HN Jr, Sabiston DC Jr. Primary cysts and neoplasms of the mediastinum: recent changes in clinical presentation, methods of diagnosis, management, and results. Ann Thorac Surg. 1987;44(3):229-37.

7. Wychulis AR, Payne WS, Clagett OT, Woolner LB. Surgical treatment of mediastinal tumors: a 40 year experience. J Thorac Cardiovasc Surg. 1971;62(3):379-92.
8. Whooley BP, Urschel JD, Antkowiak JG, Takita H. Primary tumors of the mediastinum. J Surg Oncol. 1999;70(2):95-9.

9. Bacha EA, Chapelier AR, Macchiarini P, Fadel E, Dartevelle PG. Surgery for invasive primary mediastinal tumors. Ann Thorac Surg. 1998;66(1):234-9.

10. Takeda S, Miyoshi S, Akashi A, Ohta M, Minami $\mathrm{M}$, Okumura $\mathrm{M}$, et al. Clinical spectrum of primary mediastinal tumors: a comparison of adult and pediatric populations at a single Japanese institution. J Surg Oncol. 2003;83(1):24-30.

11. Azarow KS, Pearl RH, Zurcher R, Edwards FH, Cohen AJ. Primary mediastinal masses. A comparison of adult and pediatric populations. J Thorac Cardiovasc Surg. 1993;106(1):67-72.

12. Blegvad S, Lippert H, Simper LB, Dybdahl H. Mediastinal tumours. A report of 129 cases. Scand J Thorac Cardiovasc Surg. 1990;24(1):39-42.

13. Ovrum E, Birkeland S. Mediastinal tumours and cysts. A review of 91 cases. Scand J Thorac Cardiovasc Surg. 1979;13(2):161-8.

14. Dubail D, Nyaruhirira I, Bosschaerts T, Locufier JL, Barthel J, Barroy JP. Primary mediastinal tumors. Acta Chir Belg. 1994;94(4):215-21.

15. Silva R, Gross J, Haddad F, Younes R. Intrathoracic goiter and invasive thymoma: rare concomitant presentation. J Bras Pneumol. 2006;32(4):371-4.

16. Luosto R, Koikkalainen K, Jyrälä A, Franssila K. Mediastinal tumours. A follow-up study of 208 patients. Scand J Thorac Cardiovasc Surg. 1978;12(3):253-9.

17. Davis RD Jr, Oldham HN Jr, Sabiston DC Jr. Primary cysts and neoplasms of the mediastinum: recent changes in clinical presentation, methods of diagnosis, management, and results. Ann Thorac Surg. 1987;44(3):229-37.

18. Benjamin SP, McCormack LJ, Effler DB, Groves LK. Primary tumors of the mediastinum. Chest. 1972;62(3):297-303.

19. Couto WJ, Gross JL, Deheinzelin D, Younes RN. Primary mediastinal germ cell tumors [Article in Portuguese]. Rev Assoc Med Bras. 2006;52(3):182-6.

20. Sakurai H, Asamura H, Suzuki K, Watanabe S, Tsuchiya R. Management of primary malignant germ cell tumor of the mediastinum. Jpn J Clin Oncol. 2004;34(7):386-92.

21. Wright CD. Management of thymomas. Crit Rev Oncol Hematol. 2008;65(2):109-20.

22. Greager JA, Patel MK, Briele HA, Walker MJ, Wood DK, Gupta TK. Soft tissue sarcomas of the adult thoracic wall. Cancer. 1987;59(2):370-3.

23. Tomiyama N, Müller NL, Ellis SJ, Cleverley JR, Okumura M, Miyoshi S, et al. Invasive and noninvasive thymoma: distinctive CT features. J Comput Assist Tomogr. 2001;25(3):388-93.

24. Ikezoe J, Takeuchi N, Johkoh T, Kohno N, Takashima S, Tomiyama N, et al. MRl of anterior mediastinal tumors. Radiat Med. 1992;10(5):176-83. 


\section{About the authors}

\section{Jefferson Luiz Gross}

Director. Department of Thoracic Surgery, A. C. Camargo Hospital, São Paulo, Brazil.

\section{Ulisses Augusto Correia Rosalino}

Student. Young lnvestigator Course, A. C. Camargo Hospital, São Paulo, Brazil.

\section{Riad Naim Younes}

Tenured Professor. University of São Paulo School of Medicine, São Paulo, Brazil.

\section{Fábio José Haddad}

Attending Physician. Department of Thoracic Surgery, A. C. Camargo Hospital, São Paulo, Brazil.

\section{Rodrigo Afonso da Silva}

Attending Physician. Department of Thoracic Surgery, A. C. Camargo Hospital, São Paulo, Brazil.

\section{Antonio Bomfim Marçal Avertano Rocha}

Attending Physician. Department of Thoracic Surgery, A. C. Camargo Hospital, São Paulo, Brazil. 